\title{
Preventive effects of Allium hirtifolium Boiss methanolic and aqueous extracts on renal injury induced by lead in rats
}

\author{
Nafise Hajian $^{1 *}$, Zahra Rezayatmand ${ }^{1}$, Kahin Shahanipur ${ }^{1}$ \\ ${ }^{1}$ Falavarjan Branch, Islamic Azad University, Falavarjan, Isfahan, Iran
}

\section{A R T I C L E I N F O}

Article Type:

Original Article

Article History:

Received: 7 February 2018

Accepted: 27 June 2018

\section{Keywords:}

Hepatic enzymes

Renal

Lead acetate

Shallot

\begin{abstract}
A B S T R A C T
Introduction: In this study the kidney protective effects of methanolic and aqueous extracts of Allium hirtifolium Boiss (shallot) were evaluated on kidney toxicity induced by lead ( $\mathrm{Pb}$ ) in Wistar rats.

Methods: Eighty adult female Wistar rats of 3-5 months of age and weighing 200-250 g were allocated randomly into 10 groups and treated for 15 and 30 days as follows: control group, $\mathrm{Pb}(10 \mathrm{mg} / \mathrm{L})$, methanolic extract of shallot $(12.5 \mathrm{mg} / \mathrm{kg}$ and $25 \mathrm{mg} / \mathrm{kg}), \mathrm{Pb}$ plus methanolic extract of shallot $(12.5 \mathrm{mg} / \mathrm{kg}$ and $25 \mathrm{mg} / \mathrm{kg})$, aqueous extract of shallot $(12.5 \mathrm{mg} / \mathrm{kg}$ and 25 $\mathrm{mg} / \mathrm{kg}), \mathrm{Pb}$ plus aqueous extract of shallot $(12.5 \mathrm{mg} / \mathrm{kg}$ and $25 \mathrm{mg} / \mathrm{kg})$. Serum concentrations of glucose as well as renal parameters were measured at 15 days and 30 days in the studied groups.

Results: Analysis showed a significant reduction in the mean of urea in the methanolic extract group with a concentration of $12.5 \mathrm{mg} / \mathrm{kg}$, compared to the lead group. Consumption of $25 \mathrm{mg} / \mathrm{kg}$ methanolic extract of shallot showed a significantly reduction of uric acid, creatinine and total protein in comparison with control group and lead group. Consumption of $25 \mathrm{mg} / \mathrm{kg}$ methanolic extract of shallot+lead was able to reduce the mean of urea uric acid, creatinine and total protein in comparison with lead group. Also, the results showed that methanolic extract of shallot+lead at a dose of $12.5 \mathrm{mg} / \mathrm{kg}$ could reduce the mean of urea uric acid, creatinine and total protein in comparison with lead group. There was no significant difference in the rest groups.

Conclusion: The results of the study showed that shallot extract can dose dependently reduce the factors related to lead induced renal damages.
\end{abstract}

Implication for health policy/practice/research/medical education:

Shallot extract is a natural product that might be used for prevention of renal damage, especially in case of lead toxicity.

Please cite this paper as: Hajian N, Rezayatmand Z, Shahanipur K. Preventive effects of Allium hirtifolium Boiss methanolic and aqueous extracts on renal injury induced by lead in rats. J Herbmed Pharmacol. 2018;7(3):155-159. doi: 10.15171/jhp.2018.25.

\section{Introduction}

Lead is a natural metal that is present in water and soil and enters the body through the gastrointestinal tract or respiratory tract (1). Lead has a variety of effects on hematopoiesis, the nervous system, kidneys, reproduction, and bone tissues. The signs of lead poisoning include gastrointestinal problems, colic, weight loss, weakness, anemia, brain damage, memory and learning ability loss, male infertility and sperm damage and defect, abortion, and kidney damage $(2,3)$. Lead can affect any organ or system in the body through the mechanisms that involve the basic biochemical processes involved. These mechanisms include the ability of lead to inhibit or imitate calcium and to influence proteins (4). In the interactions of proteins, lead is bound to any accessible functional group, including sulfhydryl, phosphate and carboxyl groups. Lead has a high affinity to the sulfhydryl group. It may act on the activity of zinc metaloenzymes, as zinc binds to the sulfhydryl group at the active site (4). Among the tissues, kidney has the largest concentration of lead. It causes certain pathobiological changes in the structure and function of the kidney. Lead causes cell membrane peroxidation leading to membrane fragility and change to membrane permeability and ultimately the 
destruction of the renal tubular tissues. These changes inhibit the proper functioning of the kidney via free radicals affecting the peroxidation of cell membrane lipids and renal tissue atrophy. Consequently, the concentration of the factors excreted from the kidney increases in serum. Hepatotoxicity may also occur due to an increase in serum levels of uric acid and urea (5). Chronic poisoning with lead in humans also causes lesions, such as atrophycation and fibrosis in kidney tubes which results in excessive accumulation of metabolites in the renal tubular epithelial cells $(6,7)$.

In most countries, stupendous costs are spent to treat diseases each year. The use of herbal drugs is increasing in Iran with regards to the history of herbal medicine in the country, the low cost of their preparation compared to chemical drugs, as well as few side effects compared to chemical drugs $(8,9)$. Therefore, in recent years, the research and use of herbal medicines in the treatment or reduction of various diseases such as nephrotoxicity caused by various toxins have attracted researchers (1013). Most of these plants have also shown promising results (14-16).

Allium hirtifolium Boiss, in addition to having dietary uses, has traditional therapeutic and nutritional health benefits. A. hirtifolium is an important medicinal plant that contains allicin, saponin, sapogenins and certain flavonoids such as quercetin, kaempferol, and di- and trisulfide compounds (17). Diallyl sulfide, diallyl disulfide, S-ethylcysteine, and $\mathrm{N}$-acetylcysteine are four groups of organo-sulfur substances that are isolated from plants of the Allium species such as garlic, onion, and shallot, which have been suggested to have antioxidant activities (18).

Researchers have shown that the seeds and flowers of shallot contain high concentrations of glycosylated flavonols, the most important of which are di- and trisulfide. There are reports on therapeutic and pharmaceutical properties of Allium stipitatum including antioxidant, immunoregulatory and anticancer activities (17).

Due to the present of sulfur compounds in the garlic and shallot extracts, it is likely that the antioxidant properties of these substances prevent the peroxidation of the cell membrane lipid and degradation of the kidney tissues $(19,20)$. Therefore, the aim of this study was to investigate the effect of aqueous and methanol extracts of shallot, at different concentrations, on the kidney and the serum levels of urea, uric acid, creatinine, and total protein.

\section{Materials and Methods}

Collection of plant samples

Allium hirtifolium Boiss (shallots) was collected before sprouting from Shahrekord district in Chaharmahal and Bakhtiari province, Iran. The plant specimen was authenticated and deposited at the Herbarium unit of the
College of Sciences, Isfahan University. The aerial parts of the plant were dried in shade for preparing the treatment sample, the powdered shallot (100 g) and its constituents were added to distilled water $(500 \mathrm{~mL})$ and methanol (500 mL, 90\%) to get aqueous and methanolic extracts, respectively. The solutions were filtered and used for oral administration after 48 hours. The extracts were filtered and resulting filtrates were dried using a rotary evaporator and stored at $-20^{\circ} \mathrm{C}$ until further use. For the antibacterial assays, dried extract was dissolved in dimethyl sulfoxide (DMSO) at a concentration of $100 \mathrm{mg} / \mathrm{mL}$ and stored at $4^{\circ} \mathrm{C}$ as stock solutions.

\section{Experimental Animal}

Eighty adult female Wistar rats of 3-5 months of age and weighing 200-250 g were purchased from the Razi Institute (Karaj, Iran). The rats were approved for the experiment by the local committee and were housed in individual plastic cages with stainless steel at room temperature $\left(25+3^{\circ} \mathrm{C}\right)$ at 12 hours dark-light cycles. All the rats were allowed free access to the same diets and water and acclimatized for 14 days before the treatment. Then they were divided randomly into 10 groups of 8 animals each for 15 and 30 days.

\section{Experimental design}

The control and experiment animals were divided into different groups and treated accordingly:

Group 1: Control group, fed by usual water and food Group 2: $\mathrm{Pb}$ group, fed by $\mathrm{Pb} 10 \mathrm{mg} / \mathrm{L}$ drinking water

Group 3: Group by gavage $12.5 \mathrm{mg} / \mathrm{L}$ dose of aqueous extract of shallots

Group 14: Group by gavage $25 \mathrm{mg} / \mathrm{L}$ dose of aqueous extract of shallots

Group 5: Group by gavage $12.5 \mathrm{mg} / \mathrm{L}$ dose of methanolic extract of shallots

Group 6: Group by gavage $25 \mathrm{mg} / \mathrm{L}$ dose of methanolic extract of shallots

Group 7: Group by gavage $12.5 \mathrm{mg} / \mathrm{L}$ dose of aqueous extract of shallots and $\mathrm{Pb} 10 \mathrm{mg} / \mathrm{L}$

Group 8: Group by gavage $25 \mathrm{mg} / \mathrm{L}$ dose of aqueous extract of shallots and $\mathrm{Pb} 10 \mathrm{mg} / \mathrm{L}$

Group 9: Group by gavage $12.5 \mathrm{mg} / \mathrm{L}$ dose of methanolic extract of shallots and $\mathrm{Pb} 10 \mathrm{mg} / \mathrm{L}$

Group 10: Group by gavage $12.5 \mathrm{mg} / \mathrm{L}$ dose of methanolic extract of shallot and $\mathrm{Pb} 10 \mathrm{mg} / \mathrm{L}$

Preparation of samples for biochemical analysis

After 15 days' experimentation and the end of the experimental period (30 days), blood samples were collected by the retro-orbital method using heparin coated capillaries. Serum was separated by centrifugation for 5 minutes at $1000 \times \mathrm{g}$ and stored at $-20^{\circ} \mathrm{C}$ until analysis. Serum samples were used to determine uric acid, urea, creatinine, and total protein level. All estimations were 
carried out using a diagnostic kit (Pars Azmoon test kits) as per the method described by the manufacturer.

\section{Statistical analysis}

All data were expressed as means \pm SEM. Statistical group analysis was performed with SPSS, version 22 of statistical software. One-way analysis of variance (ANOVA) was used to compare the mean values of variables among the groups. Bonferroni's test was used to identify the significance of pair wise comparison of mean values among the groups. Statistically significant differences were accepted at $P<0.05$.

\section{Results}

The present study has measured serum in renal factors in rats at the end of the experimental period and the following results were obtained.

Methanol extract of shallot in experimental groups treated with lead caused a significant reduction in renal factors (uric acid, creatinine, urea, and total protein) compared to those of the lead group.

ANOVA showed a significant reduction in the mean of urea in the methanolic extract group with a concentration of $12.5 \mathrm{mg} / \mathrm{kg}$ after 30 days of intervention, compared to the lead group (Table 1). The consumption of $25 \mathrm{mg} /$ $\mathrm{kg}$ methanolic extract of shallots for both 15 and 30 days showed a significantly reduction of uric acid, creatinine and total protein in comparison with control group and lead group (Tables 1-4).

Results underlined that the consumption of $25 \mathrm{mg} / \mathrm{kg}$ methanolic extract of shallots + lead (both 15 and 30 days) was able to reduce the mean of urea uric acid, creatinine and total protein in comparison with lead group. Also, the results showed that methanolic extract of shallot + lead at a dose of $12.5 \mathrm{mg} / \mathrm{kg}$ (both 15 and 30 days) could be useful in reduction of the mean of urea uric acid, creatinine and total protein in comparison with lead group. There was no significant difference in the rest groups.

\section{Discussion}

Lead is a per-oxidant agent, and peroxidation damage to cell membrane lipids leads to membrane fragility and change in permeability causing ultimately the destruction of the renal tubular tissue. This inhibits the proper functioning of the kidney via free radicals affecting the peroxidation of cell membrane lipids and renal tissue atrophy. Consequently, the concentration of the factors excreted from the kidney increases in serum $) 5$ (.

Table 1. Effects of shallot extracts on urea concentrations $(\mathrm{mg} / \mathrm{dL})$ in experimental groups

\begin{tabular}{|c|c|c|}
\hline Groups/length of study & 15 days & 30 days \\
\hline Control group & $1.2 \pm 60.8$ & $62.3 \pm 61.12$ \\
\hline $\mathrm{Pb} 10 \mathrm{mg} / \mathrm{kg}$ & $2.4 \pm 8.63^{\mathrm{a}}$ & $64 . \pm 66.9^{\text {a }}$ \\
\hline $12.5 \mathrm{mg} / \mathrm{L}$ dose of aqueous extract of shallot & $7.8 \pm 8.59$ & $2.52 \pm 58.0$ \\
\hline $12.5 \mathrm{mg} / \mathrm{L}$ dose of methanolic extract of shallot & $5.4 \pm 3.60$ & $2.6 \pm 56.1^{\mathrm{ab}}$ \\
\hline $25 \mathrm{mg} / \mathrm{L}$ dose of aqueous extract of shallot & $3.8 \pm 7.63$ & $6.8 \pm 0.65$ \\
\hline $25 \mathrm{mg} / \mathrm{L}$ dose of methanolic extract of shallot & $6.2 \pm 15.73$ & $02.9 \pm 8.55^{\mathrm{ab}}$ \\
\hline $12.5 \mathrm{mg} / \mathrm{L}$ dose of aqueous extract of shallot and $\mathrm{Pb} 10 \mathrm{mg} / \mathrm{L}$ & $7 \pm 16.64$ & $9 \pm 8.61$ \\
\hline $12.5 \mathrm{mg} / \mathrm{L}$ dose of methanolic extract of shallot and $\mathrm{Pb} 10 \mathrm{mg} / \mathrm{L}$ & $7.6 \pm 6.60$ & $6.1 \pm 5.62$ \\
\hline $25 \mathrm{mg} / \mathrm{L}$ dose of aqueous extract of shallot and $\mathrm{Pb} 10 \mathrm{mg} / \mathrm{L}$ & $1.3 \pm 10.65$ & $2.1 \pm 09.64$ \\
\hline $12.5 \mathrm{mg} / \mathrm{L}$ dose of methanolic extract of shallot and $\mathrm{Pb} 10 \mathrm{mg} / \mathrm{L}$ & $7.4 \pm 3.56$ & $2.4 \pm 4.55^{b}$ \\
\hline
\end{tabular}

$\mathrm{Pb}$ : lead, all values are expressed as mean $\pm \mathrm{SD}(\mathrm{n}=8)$.

a Significant difference with the control group $(P<0.05)$.

${ }^{\mathrm{b}}$ Significant difference with the $\mathrm{Pb}$ group $(P<0.05)$.

Table 2. Effects of shallot extracts on uric acid concentrations $(\mathrm{mg} / \mathrm{dL})$ in experimental groups

\begin{tabular}{|c|c|c|}
\hline Groups & 15 days & 30 days \\
\hline Control group & $6.3 \pm 20.1$ & $7.1 \pm 1.20$ \\
\hline $\mathrm{Pb} 10 \mathrm{mg} / \mathrm{kg}$ & $2.5 \pm 68.1^{\mathrm{a}}$ & $1.9 \pm 2.0^{\mathrm{a}}$ \\
\hline $12.5 \mathrm{mg} / \mathrm{L}$ dose of aqueous extract of shallot & $2 \pm 68.1$ & $2 \pm 01.2$ \\
\hline $12.5 \mathrm{mg} / \mathrm{L}$ dose of methanolic extract of shallot & $15.3 \pm 59.1$ & $2.3 \pm 1.67$ \\
\hline $25 \mathrm{mg} / \mathrm{L}$ dose of aqueous extract of shallot & $2.4 \pm 52.1$ & $4.1 \pm 1.67$ \\
\hline $25 \mathrm{mg} / \mathrm{L}$ dose of methanolic extract of shallot & $2.4 \pm 19.1^{\mathrm{ab}}$ & $2.4 \pm 1.19^{\mathrm{ab}}$ \\
\hline $12.5 \mathrm{mg} / \mathrm{L}$ dose of aqueous extract of shallot and $\mathrm{Pb} 10 \mathrm{mg} / \mathrm{L}$ & $2.4 \pm 68.1$ & $5.2 \pm 67.1$ \\
\hline $12.5 \mathrm{mg} / \mathrm{L}$ dose of methanolic extract of shallot and $\mathrm{Pb} 10 \mathrm{mg} / \mathrm{L}$ & $7.6 \pm 6.60$ & $6.1 \pm 5.62$ \\
\hline $25 \mathrm{mg} / \mathrm{L}$ dose of aqueous extract of shallot and $\mathrm{Pb} 10 \mathrm{mg} / \mathrm{L}$ & $1.3 \pm 10.65$ & $2.1 \pm 09.64$ \\
\hline $12.5 \mathrm{mg} / \mathrm{L}$ dose of methanolic extract of shallot and $\mathrm{Pb} 10 \mathrm{mg} / \mathrm{L}$ & $7.4 \pm 3.56$ & $2.4 \pm 4.55^{b}$ \\
\hline
\end{tabular}

$\mathrm{Pb}$ : lead, all values are expressed as mean $\pm S D(n=8)$.

a Significant difference with the control group $(P<0.05)$.

${ }^{\mathrm{b}}$ Significant difference with the $\mathrm{Pb}$ group $(P<0.05)$. 
Table 3. Effects of shallot extracts on creatinine concentrations $(\mathrm{mg} / \mathrm{dL})$ in experimental groups

\begin{tabular}{lll}
\hline Groups & 15 days & 30 days \\
\hline Control group & $6.0 \pm 63.0$ & $10.0 \pm 66.0$ \\
$\mathrm{~Pb} 10 \mathrm{mg} / \mathrm{kg}$ & $3.0 \pm 79.0^{\mathrm{a}}$ & $9.0 \pm 0.84^{\mathrm{a}}$ \\
$12.5 \mathrm{mg} / \mathrm{L}$ dose of aqueous extract of shallot & $3.0 \pm 0.62$ & $6.0 \pm 65.0$ \\
$12.5 \mathrm{mg} / \mathrm{L}$ dose of methanolic extract of shallot & $4.0 \pm 0.62$ & $0.0 \pm 65.0$ \\
$25 \mathrm{mg} / \mathrm{L}$ dose of aqueous extract of shallot & $1.0 \pm 0.63$ & $5.0 \pm 65.0$ \\
$25 \mathrm{mg} / \mathrm{L}$ dose of methanolic extract of shallot & $3.0 \pm 0.62^{\mathrm{a}}$ & $4.0 \pm 63.0^{\mathrm{a}}$ \\
$12.5 \mathrm{mg} / \mathrm{L}$ dose of aqueous extract of shallot and $\mathrm{Pb} 10 \mathrm{mg} / \mathrm{L}$ & $6.0 \pm 0.83$ & $1.0 \pm 83.0$ \\
$12.5 \mathrm{mg} / \mathrm{L}$ dose of methanolic extract of shallot and $\mathrm{Pb} 10 \mathrm{mg} / \mathrm{L}$ & $1.0 \pm 0.73^{\mathrm{b}}$ & $7.0 \pm 73.0^{\mathrm{b}}$ \\
$25 \mathrm{mg} / \mathrm{L}$ dose of aqueous extract of shallot and $\mathrm{Pb} 10 \mathrm{mg} / \mathrm{L}$ & $1.0 \pm 0.79$ & $1.0 \pm 83.0$ \\
$12.5 \mathrm{mg} / \mathrm{L}$ dose of methanolic extract of shallot and $\mathrm{Pb} 10 \mathrm{mg} / \mathrm{L}$ & $1.0 \pm 83.0^{\mathrm{b}}$ & $1.0 \pm 66.0^{\mathrm{b}}$ \\
\hline
\end{tabular}

$\mathrm{Pb}$ : lead, all values are expressed as mean $\pm S D(n=8)$.

${ }^{a}$ Significant difference with the control group $(P<0.05)$.

${ }^{\mathrm{b}}$ Significant difference with the $\mathrm{Pb}$ group $(P<0.05)$.

Table 4. Effects of shallot extracts on total protein concentrations $(\mathrm{mg} / \mathrm{dL})$ in experimental groups

\begin{tabular}{lll}
\hline Groups & $\mathbf{1 5}$ days & 30 days \\
\hline Control group & $4.6 \pm 8.8$ & $5.4 \pm 0.8$ \\
$\mathrm{~Pb} 10 \mathrm{mg} / \mathrm{kg}$ & $6.3 \pm 7.9^{\mathrm{a}}$ & $4.3 \pm 8.7^{\mathrm{a}}$ \\
$12.5 \mathrm{mg} / \mathrm{L}$ dose of aqueous extract of shallot & $3.6 \pm 7.8$ & $6.3 \pm 3.8$ \\
$12.5 \mathrm{mg} / \mathrm{L}$ dose of methanolic extract of shallot & $6.2 \pm 6.8$ & $6.3 \pm 0.8$ \\
$25 \mathrm{mg} / \mathrm{L}$ dose of aqueous extract of shallot & $6.3 \pm 8.9$ & $6.3 \pm 7.8$ \\
$25 \mathrm{mg} / \mathrm{L}$ dose of methanolic extract of shallot & $6.3 \pm 6.7^{\mathrm{ab}}$ & $3.3 \pm 5.7^{\mathrm{ab}}$ \\
$12.5 \mathrm{mg} / \mathrm{L}$ dose of aqueous extract of shallot and $\mathrm{Pb} 10 \mathrm{mg} / \mathrm{L}$ & $2.6 \pm 7.3$ & $1.08 \pm 8.0$ \\
$12.5 \mathrm{mg} / \mathrm{L}$ dose of methanolic extract of shallot and $\mathrm{Pb} 10 \mathrm{mg} / \mathrm{L}$ & $6.2 \pm 4.8$ & $8.2 \pm 8.0$ \\
$25 \mathrm{mg} / \mathrm{L}$ dose of aqueous extract of shallot and $\mathrm{Pb} 10 \mathrm{mg} / \mathrm{L}$ & $6.1 \pm 8.8$ & $6.2 \pm 6.8$ \\
$12.5 \mathrm{mg} / \mathrm{L}$ dose of methanolic extract of shallot and $\mathrm{Pb} 10 \mathrm{mg} / \mathrm{L}$ & $6.3 \pm 4.7^{\mathrm{ab}}$ & $3.3 \pm 4.7^{\mathrm{ab}}$ \\
\hline
\end{tabular}

$\mathrm{Pb}$ : lead, all values are expressed as mean $\pm S D(n=8)$.

${ }^{a}$ Significant difference with the control group $(P<0.05)$.

${ }^{\mathrm{b}}$ Significant difference with the $\mathrm{Pb}$ group $(P<0.05)$.

Methanol extract of shallot in experimental groups treated with lead caused a significant reduction in renal factors (uric acid, creatinine, urea, and total protein) compared to those of the lead group. Shallot is an antioxidant that prevents lipid peroxidation (5,21). Shallot has sulfur components such as allyl propyl disulfide and flavonoids such as quercetin that have antioxidant properties $(22,23)$. In the study of Johari et al., it was also observed that receiving $0.6 \mathrm{~g} / \mathrm{L}$ of lead, caused an increase in serum urea levels in rats. In another study on the effect of garlic extract on the elimination of lead-induced toxicity in the kidneys of baby rats, the renal factors including urea, uric acid, and creatinine significantly increased when compared to the control group (24). Since the serum concentrations of these factors are indices for evaluation of kidney damage, it can be concluded that lead, due to oxidative stress and destruction of tubules, and consequently atrophy and necrosis, causes severe kidney damage, obviously followed by a decrease in blood purification rate.

The efficacy of shallot is probably due to containing free carboxyl and amino groups. These bioactive compounds reduce the amount of lead and increase its excretion from the blood and tissues in which lead is accumulated. It also reduces the absorption of lead from the digestive tract. The therapeutic potential of shallot is due to the effect of its compounds on lead absorption and its excretion from the body. Probably, the sulfur compounds in the methanol extract of shallot can prevent lipid peroxidation and cell membrane degradation, and therefore atrophy of the kidney tissue by directly influencing free radicals and removing them from the cells, and increasing catalase and superoxide dismutase, so that the kidney functions more appropriately.

\section{Conclusion}

Lead, due to oxidative stress and destruction of tubules, and consequently atrophy and necrosis, causes severe kidney damage, followed by a decrease in blood purification rate. Shallot was able to reduce the serum concentrations of the indices for kidney damage. Hence, it might be used for prevention of renal damage, especially in case of lead toxicity.

\section{Authors' contributions}

All authors contributed to the study. $\mathrm{NH}$ and ZR acquired data. $\mathrm{NH}$ prepared the drafting. $\mathrm{ZR}$ and $\mathrm{KSH}$ revised it critically for important intellectual content and $\mathrm{NH}$ submitted it. All read and confirmed the article ready for publication. 


\section{Conflict of interests}

The authors declared no competing interests exist.

\section{Ethical considerations}

The study was approved by the Ethical Committee of Islamic Azad University, Falavarjan, Isfahan, Iran (17230520952007). Ethical issues (including plagiarism, misconduct, data fabrication, falsification, double publication or submission, redundancy) have been completely observed by the authors.

\section{Funding/Support}

This research was financially supported by Islamic Azad University, Falavarjan, Isfahan, Iran, and the authors.

\section{References}

1. Kazantzis G. Role of cobalt, iron, lead, manganese, mercury, platinum, selenium, and titanium in carcinogenesis. Environ Health Perspect. 1981;40:143-61.

2. Telisman S, Colak B, Pizent A, Jurasovic J, Cvitkovic P. Reproductive toxicity of low-level lead exposure in men. Environ Res. 2007;105(2):256-66. doi: 10.1016/j. envres.2007.05.011.

3. Abdelouahab N, Mergler D, Takser L, Vanier C, St-Jean $\mathrm{M}$, Baldwin $\mathrm{M}$, et al. Gender differences in the effects of organochlorines, mercury, and lead on thyroid hormone levels in lakeside communities of Quebec (Canada). Environ Res. 2008;107(3):380-92. doi: 10.1016/j.envres.2008.01.006.

4. Ford MD. Clinical Toxicology. Philadelphia: Saunders; 2001.

5. Elsaid FG, Elkomy MM. Aqueous garlic extract and sodium thiosulphate as antidotes for cyanide intoxication in albino rats. Res J Med Med Sci. 2006;1(2):50-6.

6. Goyer RA. Effect of toxic, chemical, and environmental factors on the kidney. Monogr Pathol. 1979;20:202-17.

7. Segasothy M, Samad SA, Zulfigar A, Bennett WM. Chronic renal disease and papillary necrosis associated with the long-term use of nonsteroidal anti-inflammatory drugs as the sole or predominant analgesic. Am J Kidney Dis. 1994;24(1):17-24.

8. Movahedian A, Asgary S, Mansoorkhani HS, Keshvari M. Hepatotoxicity effect of some Iranian medicinal herbal formulation on rats. Adv Biomed Res. 2014;3:12. doi: 10.4103/2277-9175.124641.

9. Farsani MK, Amraie E, Kavian P, Keshvari M. Effects of aqueous extract of alfalfa on hyperglycemia and dyslipidemia in alloxan-induced diabetic Wistar rats. Interv Med Appl Sci. 2016;8(3):103-8. doi: 10.1556/1646.8.2016.3.5.

10. Sedighi M, Noori-Ahmadabadi M, Rafieian-Kopaei M, Ebrahimpoor-Samani J, Shahinfard N. The effect of Rosa damascena Mill Hydro-alcoholic extract on the ileum contraction in rat. J Mazandaran Univ Med Sci. 2014;23(108):30-9.

11. Asgary S, Rastqar A, Keshvari M. Functional food and cardiovascular disease prevention and treatment: a review. J Am Coll Nutr. 2018:1-27. doi: 10.1080/07315724.2017.1410867.

12. Lorigooini Z, Ayatollahi SA, Amidi S, Kobarfard F. Evaluation of anti-platelet aggregation effect of some Allium species. Iran J Pharm Res. 2015;14(4):1225-31.

13. Rabiei Z, Bigdeli M, Lorigooini Z. A review of medicinal herbs with antioxidant properties in the treatment of cerebral ischemia and reperfusion. J Babol Univ Med Sci. 2015;17(12):47-56. doi: 10.22088/jbums.17.12.47.

14. Ghasemi S, Lorigooini Z. A review of significant molecular mechanisms of flavonoids in prevention of prostate cancer. J Chem Pharm Sci. 2016;9(4):3388-94.

15. Moradi MT, Karimi A, Lorigooini Z. Alkaloids as the natural anti-influenza virus agents: a systematic review. Toxin Rev. 2018;37(1):11-8. doi: 10.1080/15569543.2017.1323338.

16. Asgari S, Ansari Samani R, Deris F, Shahinfard N, Salimi M, Mortazaei S, et al. Antioxidant activity and the lowering effect of hydroalcoholic extract of Allium hirtifolium Boisson some haemostatic factors in hypercholesterolemic rabbits. J Mazandaran Univ Med Sci. 2012;22(91):40-8.

17. Kusterer J, Vogt A, Keusgen M. Isolation and identification of a new cysteine sulfoxide and volatile sulfur compounds from Allium subgenus Melanocrommyum. J Agric Food Chem. 2010;58(1):520-6. doi: 10.1021/jf902294c.

18. Ghafouri-Khosrowshahi A, Farzami B, MohammadiBardbori A. The inhibitory effect of garlic extract on formation of glycated hemoglobin and AGEPs. J Med Sci. 2007;7(6):1039-43. doi: 10.3923/jms.2007.1039.1043.

19. Senapati SK, Dey S, Dwivedi SK, Swarup D. Effect of garlic (Allium sativum L.) extract on tissue lead level in rats. J Ethnopharmacol. 2001;76(3):229-32.

20. Mehdi M, Javad H, Seyed-Mostafa HZ, Mohammadreza M, Ebrahim M. The effect of Persian shallot (Allium hirtifolium Boiss.) extract on blood sugar and serum levels of some hormones in diabetic rats. Pak J Pharm Sci. 2013;26(2):397402.

21. Ni Z, Hou S, Barton CH, Vaziri ND. Lead exposure raises superoxide and hydrogen peroxide in human endothelial and vascular smooth muscle cells. Kidney Int. 2004;66(6):232936. doi: 10.1111/j.1523-1755.2004.66032.x.

22. Ghodrati Azadi H, Ghaffari SM, Riazi GH, Ahmadian S, Vahedi F. Antiproliferative activity of chloroformic extract of Persian Shallot, Allium hirtifolium, on tumor cell lines. Cytotechnology. 2008;56(3):179-85. doi: 10.1007/s10616008-9145-0.

23. Ghodrati Azadi H, Riazi GH, Ghaffari SM, Ahmadian S, Khalife TJ. Effects of Allium hirtifolium (Iranian shallot) and its allicin on microtubule and cancer cell lines. Afr J Biotechnol. 2009;8(19):5030-7

24. Johari H, Zamani Z, Mokhtari M, Hemayatkhah Jahromi V, Jamali H, Yazdani M. The investigation of garlic (Allium sativum) extract on lead detoxification of neonatal rats kidney. J Fasa Univ Med Sci. 2014;4(1):90-8. 